\title{
ACE (I/D) polymorphism and response to treatment in coronary artery disease: a comprehensive database and meta-analysis involving study quality evaluation Georgios Kitsios ${ }^{1,2}$ and Elias Zintzaras*1,2
}

Address: ${ }^{1}$ Department of Biomathematics, University of Thessaly School of Medicine, Larissa, Greece and ${ }^{2}$ Center for Clinical Evidence Synthesis, Institute for Clinical Research and Health Policy Studies, Department of Medicine, Tufts Medical Center, Tufts University School of Medicine, 800 Washington Street, Tufts MC \#63, Boston, MA 02111, USA

Email: Georgios Kitsios - GKitsios@tuftsmedicalcenter.org; Elias Zintzaras* - ezintzaras@tuftsmedicalcenter.org

* Corresponding author

Published: 4 June 2009

BMC Medical Genetics 2009, 10:50 doi:10.1186/147/-2350-10-50
Received: 12 September 2008

Accepted: 4 June 2009

This article is available from: http://www.biomedcentral.com/147/-2350/10/50

(C) 2009 Kitsios and Zintzaras; licensee BioMed Central Ltd.

This is an Open Access article distributed under the terms of the Creative Commons Attribution License (http://creativecommons.org/licenses/by/2.0), which permits unrestricted use, distribution, and reproduction in any medium, provided the original work is properly cited.

\begin{abstract}
Background: The role of angiotensin-converting enzyme (ACE) gene insertion/deletion (I/D) polymorphism in modifying the response to treatment modalities in coronary artery disease is controversial.

Methods: PubMed was searched and a database of 58 studies with detailed information regarding ACE I/D polymorphism and response to treatment in coronary artery disease was created. Eligible studies were synthesized using meta-analysis methods, including cumulative meta-analysis. Heterogeneity and study quality issues were explored.

Results: Forty studies involved invasive treatments (coronary angioplasty or coronary artery bypass grafting) and 18 used conservative treatment options (including anti-hypertensive drugs, lipid lowering therapy and cardiac rehabilitation procedures). Clinical outcomes were investigated by II studies, while 47 studies focused on surrogate endpoints. The most studied outcome was the restenosis following coronary angioplasty ( 34 studies). Heterogeneity among studies $(p<0.01)$ was revealed and the risk of restenosis following balloon angioplasty was significant under an additive model: the random effects odds ratio was I.42 (95\% confidence interval:I.07-I.9I). Cumulative meta-analysis showed a trend of association as information accumulates. The results were affected by population origin and study quality criteria. The meta-analyses for the risk of restenosis following stent angioplasty or after angioplasty and treatment with angiotensin-converting enzyme inhibitors produced non-significant results. The allele contrast random effects odds ratios with the $95 \%$ confidence intervals were $1.04(0.92-1.16)$ and $1.10(0.81-1.48)$, respectively. Regarding the effect of ACE I/D polymorphism on the response to treatment for the rest outcomes (coronary events, endothelial dysfunction, left ventricular remodeling, progression/regression of atherosclerosis), individual studies showed significance; however, results were discrepant and inconsistent.
\end{abstract}

Conclusion: In view of available evidence, genetic testing of ACE I/D polymorphism prior to clinical decision making is not currently justified. The relation between $A C E$ genetic variation and response to treatment in CAD remains an unresolved issue. The results of long-term and properly designed prospective studies hold the promise for pharmacogenetically tailored therapy in CAD. 


\section{Background}

Coronary artery disease (CAD), including its most severe complication, myocardial infarction (MI), is a complex disorder resulting from the interaction between genetic and environmental factors. Despite extensive efforts using the candidate gene approach or genome-wide linkage studies, the responsible molecular and genetic determinants remain largely unidentified [1,2]. Recently, genome-wide association studies provided more convincing evidence for CAD-associated genomic loci, generating cautious optimism for disentangling the disease pathophysiology and defining novel targets for treatment [3].

CAD mortality has been falling consistently in western countries, as a result of population-wide improvements in cardiovascular risk factors and modern cardiology treatments for CAD patients [4]. Nevertheless, a considerable inter-individual variability in response to the various treatment modalities for CAD, both invasive and pharmacological, has been described [5]. Given the large number of interventions currently available for the treatment and prevention of CAD and the large number of patients eligible to receive them, even small sources of variation in efficacy and safety have important implications for public health. An important source of variability in response to treatment is attributed to the patient's genetic profile $[1,4,5]$.

Among the most studied genes for its implication in pathogenesis of CAD and related outcomes is angiotensin converting enzyme (ACE) gene, located on chromosome 17 q23 [6-8]. The genetic polymorphism in intron 16, characterized by an insertion (I) or a deletion (D) of a 287 noncoding base pair Alu repeat sequence (dbSNP rs4646994) has been correlated with the levels of circulating, intracellular and heart tissue activity of ACE [9]. Apart from conferring susceptibility, the ACE gene has been also proposed to play a role in modifying the effect of various treatments in CAD. This potential modifying role has been investigated by numerous studies on several treatment-outcome settings. However, the available evidence published to date is weak, owing to sparseness of data or disagreements among studies. The aim of this study is to summarize the available ACE $I / D$ and response-to-treatment studies for CAD and, where applicable, to quantify the effect size of the estimated risk associated with this polymorphism by meta-analysis.

\section{Methods}

\section{Selection of studies}

A comprehensive search of the PubMed database from its inception through March 2008 was conducted. We combined search terms for ACE genotype and CAD. Search terms included (ACE OR angiotensin converting enzyme)
AND (gene OR polymorphism OR genetic variant) AND (myocardial infarction OR coronary artery disease OR coronary heart disease OR ischemic heart disease OR myocardial ischemia OR angina OR acute coronary syndrome). The retrieved studies were manually screened to assess their appropriateness for inclusion criteria. All references cited in the studies were also reviewed to identify additional published articles not indexed in the PubMed database. Case reports, editorials and review articles were excluded. The search was restricted to English-language articles of studies in humans.

The review included genetic association studies fulfilling the following inclusion criteria: (1) providing cases diagnosed with CAD or cohorts followed for CAD development, (2) using guideline-incorporated primary or secondary prevention measures for CAD [10-13], (3) investigating clinical outcomes of CAD (in primary or secondary prevention studies) or surrogate outcomes predicting clinical events in CAD patients, (4) providing information on genotype frequency for ACE I/D polymorphism or estimated genetic effects on response to treatment, and (5) using validated molecular methods for genotyping. Studies investigating susceptibility, progression, severity or survival, irrespective of treatment effect, were excluded from this review.

\section{Data extraction}

Two investigators (GK and EZ) independently extracted data. The extracted data included information about the study design characteristics, the assessed outcomes, the cohort characteristics, the intervention used and finally, the reported results. Disagreements were resolved through consensus. The quality of each study was also critically assessed by reporting a composite quality score to allow comparison among studies.

\section{Data synthesis - Statistical analysis}

For each study, the statistical significance of the main findings for each treatment-outcome group was recorded or the respective odds ratios were calculated by the extracted genotypic frequencies.

In the case of studies with similar outcome definition criteria, identical intervention and available genotype frequency for each group, a meta-analysis was performed (see results). Three meta-analyses were performed to investigate the association between $A C E I / D$ and the risk of restenosis after angioplasty for the allele contrast ( $D$ vs $I)$, the recessive (DD vs. $I D / I I)$, the dominant $(D D / I D$ vs. $I I$ ), the additive ( $D D$ vs $I I$ ) and the co-dominant (ID vs $\mathrm{DD} / \mathrm{II}$ ) models. We calculated the overall odds ratio (OR) with the corresponding 95\% confidence interval (CI) using the fixed effects (FE) and random effects (RE; DerSi- 
monian and Laird) models. Statistical heterogeneity across the various studies was tested with the use of $Q$-statistic [14]. A p value $<0.10$ indicated a significant statistical heterogeneity across studies, allowing for the use of RE model.

A cumulative and recursive cumulative meta-analysis was also carried out $[6,14]$. Cumulative and recursive cumulative meta-analyses provide a framework for updating a genetic effect from all studies and a measure of how much the genetic effect changes as evidence accumulates. Thus, cumulative meta-analysis indicates the trend in estimated risk effect and recursive cumulative meta-analysis indicates the stability in risk effect. In cumulative meta-analysis, studies were chronologically ordered by publication year, then, the pooled ORs were obtained at the end of each year, i.e. at each information step. In recursive cumulative meta-analysis, the relative change in pooled OR in each information step (pooled OR in next year/pooled OR in current year) was calculated. A differential magnitude of effect comparing large versus small studies for the allele contrast was verified using the Egger regression test [15].

In addition to the main (or overall) analysis which included all available data, a subgroup analysis for each "race" was also performed. 'Racial' descent was categorized into Caucasian descents (European and American whites), East Asian descents, mixed and populations of Turkish ancestry [14].

The impact of study quality was assessed by performing subgroup analysis on studies with high quality and low quality components. The following parameters were considered as quality components: A. Internal validity criteria: homogeneous study group, blindness of genotyping, registration of loss to follow up, genotyping procedure (original procedure or use of Insertion-specific primers) [16], genotyping replication with another protocol, blindness and objectiveness of angiograms assessment. B. Data description and analysis criteria: data by gender provided, power calculations provided, overlapping with previous studies, description of cases recruitment procedure, assessment of gene-gene interactions, control for possible clinical and other modifiers between genotypes, control of co-interventions that bear on outcome for each genotype, availability of data, appropriate statistics-description and discussion of possible genetic effects. High quality studies were defined as studies that exceeded the median quality score [6].

Analyses were performed using StatsDirect (StatsDirect Ltd), Compaq Visual Fortran90, and GLIM3.77.44-50 [6].

\section{Results \\ Eligible studies}

The literature search identified 759 citations. All citations identified through the literature search were independently screened by two investigators (GK and EZ) according to the inclusion criteria. Two hundred fifty-nine articles were retrieved and evaluated against the same criteria. Data from 58 articles [17-74] that investigated the association between $A C E I / D$ polymorphism and response to treatment in CAD met the inclusion criteria, and were included in the review. Next, data from 28 studies [17$26,29-37,42-46,49]$ met the meta-analysis eligibility criteria and were included in the context of three meta-analyses. Figure 1 presents a flow chart of retrieved studies and studies excluded, with specification of reasons.

\section{Summary statistics}

Details from studies included in our database are provided in Table 1 and Additional file 1. The interventions investigated were classified in two major categories: invasive (40 studies) and conservative (18 studies). The invasive treatments included coronary revascularization by percutaneous transluminal coronary angioplasty (PTCA) and coronary artery by-pass grafting (CABG). The conservative treatments included pharmacological interventions (16 studies) or cardiac rehabilitation procedures (two studies). The investigated outcomes were classified as clinical (11 studies) or surrogate (47 studies). The populations enrolled were of Caucasian (39 studies), East Asian (10 studies), mixed (six studies) or Turkish ancestry (three studies). Regarding study designs, our database included 44 cohort studies, eight randomized controlled trials, five cross-sectional and one retrospective study.

We now present the results for each intervention in turn.

\section{Invasive treatment strategies}

\section{Percutaneous transluminal coronary angioplasty}

Since the first reports of successful angioplasty of coronary atherosclerotic lesions, restenosis has been encountered as a significant limitation to the long-term efficacy of the procedure. Restenosis is an angiographically-defined outcome correlated with reduction in the quality of life and increase in the morbidity or even the mortality of patients [75]. Stenting has rapidly become the preferred method for PTCA, since it has distinct advantages over balloon angioplasty alone, including the reduction of the rate of restenosis from $50 \%$ to $20 \%$ [76].

Restenosis has been fitted into the standard multifactorial model of complex disease, although classical genetic epidemiological studies (twin or extended family studies) needed to establish the heritability of the phenotype are not practical and have not been conducted. Moreover, 

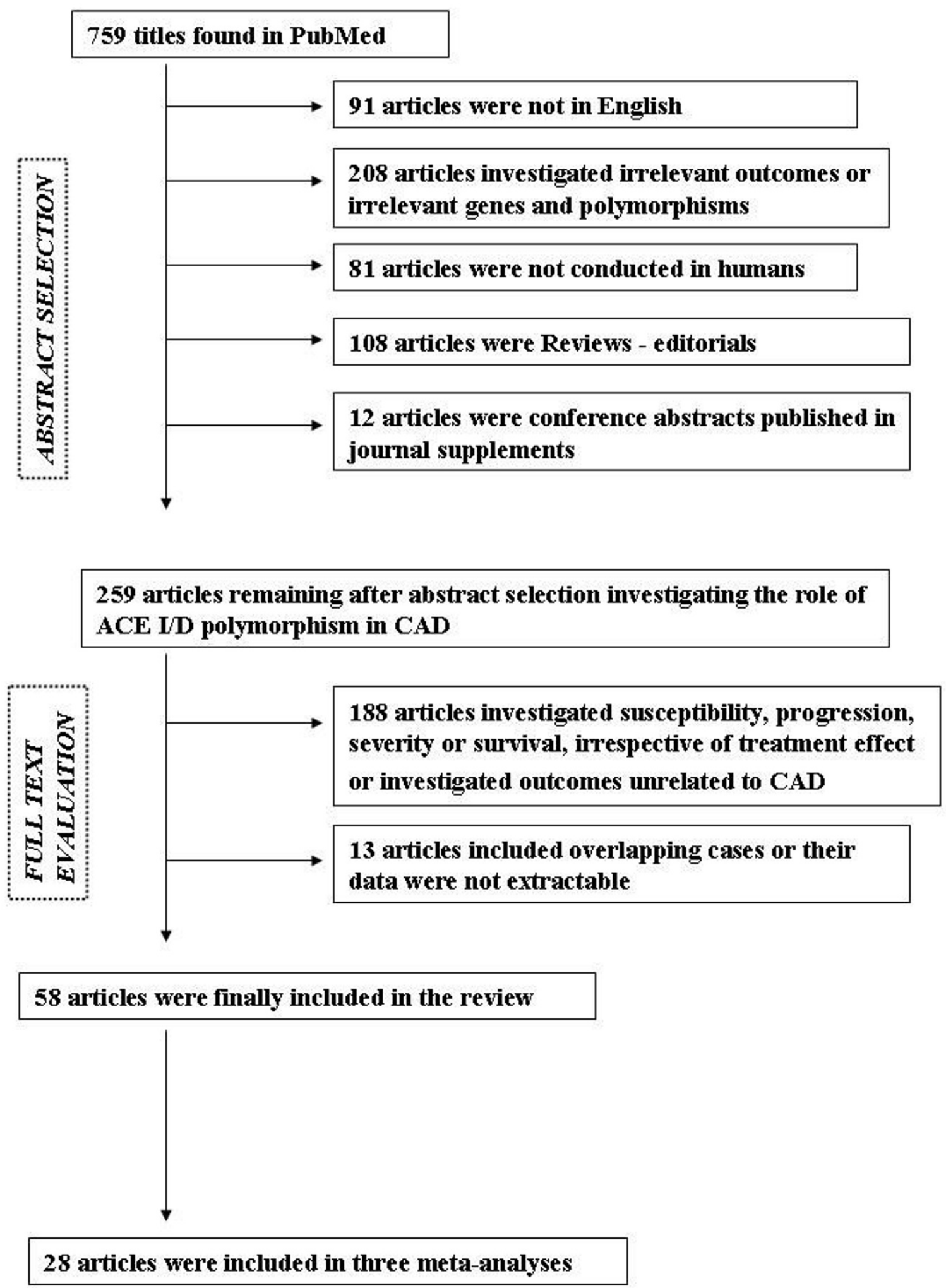

Figure I

Flow chart of retrieved studies and studies excluded, with specification of reasons. 
Table I: Summary information of studies included in the meta-analyses.

\begin{tabular}{|c|c|c|c|c|c|c|}
\hline $\begin{array}{l}\text { First author, } \\
\text { Year, Country } \\
\text { [ref] }\end{array}$ & $\begin{array}{l}\text { Study design, } \\
\text { duration of FU }\end{array}$ & $\begin{array}{l}\text { Cohort description } \\
\text { [No of patients (M/ } \\
\text { F), Ethnicity, Mean } \\
\text { Age (SD), inclusion } \\
\text { criteria] }\end{array}$ & $\begin{array}{l}\text { Restenosis } \\
\text { definition criteria }\end{array}$ & Intervention & $\begin{array}{l}\text { Gene-gene } \\
\text { interaction } \\
\text { assessed? } \\
\text { (gene) }\end{array}$ & Quality score \\
\hline & & & & $\begin{array}{l}\text { Balloon } \\
\text { angioplasty }\end{array}$ & & \\
\hline $\begin{array}{l}\text { Volzke, } 2000, \\
\text { Germany [17] }\end{array}$ & $\begin{array}{l}\text { cohort } \\
6 \text { months }\end{array}$ & $\begin{array}{l}\text { 5II (388/I } 23) \text {, } \\
\text { Caucasians, } 60.6(8.6) \text {, } \\
\text { CAD patients } \\
\text { undergoing elective } \\
\text { PTCA of a previously } \\
\text { untreated native } \\
\text { coronary artery }\end{array}$ & $\begin{array}{l}>50 \% \text { progression of } \\
\text { the residual stenosis } \\
\text { at FU }\end{array}$ & PTCA-balloon & No & 35 \\
\hline $\begin{array}{l}\text { Yoshida, 1999, } \\
\text { Japan [18] }\end{array}$ & $\begin{array}{l}\text { cohort } \\
5.21(3.9) \text { years }\end{array}$ & $\begin{array}{l}\text { I } 23 \text { (nr), East Asians, } \\
58.2(10.2), \text { MI patients } \\
\text { undergoing PTCA } \\
\text { discharged from } \\
\text { hospital at the start of } \\
\text { FU }\end{array}$ & $\mathrm{nr}$ & PTCA-balloon & No & 30 \\
\hline $\begin{array}{l}\text { Kasi, 1996, Spain } \\
\text { [19] }\end{array}$ & $\begin{array}{l}\text { cohort } \\
6 \text { months }\end{array}$ & $\begin{array}{l}69(57 / / 2) \text {, Caucasians, } \\
58 \text { (9.9), UA patients } \\
\text { undergoing PTCA }\end{array}$ & $\begin{array}{l}\text { diameter stenosis > } \\
50 \% \text { at FU }\end{array}$ & PTCA-balloon & No & 27 \\
\hline $\begin{array}{l}\text { Kamitani, 1995, } \\
\text { Japan [20] }\end{array}$ & $\begin{array}{l}\text { cohort } \\
6 \text { months }\end{array}$ & $\begin{array}{l}103(103 / 00), \text { East } \\
\text { Asians, } 52(1), \text { Primary } \\
\text { PTCA for MI patients }\end{array}$ & $\begin{array}{l}>50 \% \text { progression of } \\
\text { the residual stenosis } \\
\text { at FU }\end{array}$ & PTCA-balloon & No & 27 \\
\hline $\begin{array}{l}\text { Samani, 1995, UK } \\
\text { [2I] }\end{array}$ & $\begin{array}{l}\text { cohort } \\
4 \text { months }\end{array}$ & $\begin{array}{l}233(194 / 39), \mathrm{nr}, 56 \\
\text { (I), single-vessel PTCA } \\
\text { in the Subcutaneous } \\
\text { Heparin and } \\
\text { Angioplasty Restenosis } \\
\text { Prevention (SHARP) } \\
\text { study }\end{array}$ & $\begin{array}{l}>50 \% \text { progression of } \\
\text { the residual stenosis } \\
\text { at FU }\end{array}$ & PTCA-balloon & No & 34 \\
\hline $\begin{array}{l}\text { van Bockxmeer, } \\
\text { 1995, Australia } \\
\text { [22] }\end{array}$ & $\begin{array}{l}\text { cohort } \\
6 \text { months }\end{array}$ & $\begin{array}{l}207 \text { (I } 70 / 37), \\
\text { Caucasians, } 57 \text { (9), } \\
\text { CAD patients } \\
\text { undergoing elective } \\
\text { PTCA }\end{array}$ & $\begin{array}{l}>50 \% \text { progression of } \\
\text { the residual stenosis } \\
\text { at FU }\end{array}$ & PTCA-balloon & Yes (APOE) & 33 \\
\hline $\begin{array}{l}\text { Tsukada, 1997, } \\
\text { Japan [23] }\end{array}$ & $\begin{array}{l}\text { cohort } \\
3 \text { months }\end{array}$ & $\begin{array}{l}96(\mathrm{nr}) \text {, East Asians, } 60 \\
\text { (I.0), CAD patients } \\
\text { undergoing elective } \\
\text { PTCA }\end{array}$ & $\begin{array}{l}\text { diameter stenosis > } \\
50 \% \text { at FU }\end{array}$ & PTCA-balloon & No & 28 \\
\hline $\begin{array}{l}\text { Beohar, 1995, } \\
\text { USA [24] }\end{array}$ & $\begin{array}{l}\text { cohort } \\
3 \text { months }\end{array}$ & $\begin{array}{l}89(\mathrm{nr}), \text { Caucasians, } \\
63.9(10), \text { CAD } \\
\text { patients undergoing } \\
\text { elective PTCA }\end{array}$ & $\begin{array}{l}\text { diameter stenosis > } \\
50 \% \text { at FU }\end{array}$ & PTCA-balloon & No & 24 \\
\hline $\begin{array}{l}\text { Zee, 200I, Spain } \\
{[25]}\end{array}$ & $\begin{array}{l}\text { cohort } \\
6 \text { months }\end{array}$ & $\begin{array}{l}342(305 / 37), \\
\text { Caucasians, } 58.9(9.6), \\
\text { CAD patients } \\
\text { undergoing PTCA }\end{array}$ & $\begin{array}{l}>50 \% \text { progression of } \\
\text { the residual stenosis } \\
\text { at FU }\end{array}$ & PTCA-balloon & No & 37 \\
\hline $\begin{array}{l}\text { Ohishi, 1993, } \\
\text { Japan [26] }\end{array}$ & $\begin{array}{l}\text { cohort } \\
6 \text { months }\end{array}$ & $\begin{array}{l}82 \text { (nr), East Asians, nr, } \\
\text { MI patients undergoing } \\
\text { primary PTCA }\end{array}$ & $\begin{array}{l}>50 \% \text { progression of } \\
\text { the residual stenosis } \\
\text { at FU }\end{array}$ & PTCA-balloon & No & 23 \\
\hline \multirow[t]{2}{*}{$\begin{array}{l}\text { Hamon, } 1998, \\
\text { France [37] }\end{array}$} & $\begin{array}{l}\text { cohort } \\
6 \text { months }\end{array}$ & $\begin{array}{l}27 \text { I (229/42), } \\
\text { Caucasians, } 60 \text { (10), } \\
\text { CAD patients } \\
\text { undergoing PTCA }\end{array}$ & $\begin{array}{l}\text { diameter stenosis > } \\
50 \% \text { at FU }\end{array}$ & PTCA-balloon & Yes (AGTIR) & 34 \\
\hline & & & & $\begin{array}{l}\text { Angioplasty } \\
\text { with stent } \\
\text { deployment }\end{array}$ & & \\
\hline $\begin{array}{l}\text { Amant, 1997, } \\
\text { France [30] }\end{array}$ & $\begin{array}{l}\text { cohort } \\
6 \text { months }\end{array}$ & $\begin{array}{l}\text { I } 46 \text { (I I I/29), } \\
\text { Caucasians, } 60 \text { (I0) } \\
\text { CAD patients } \\
\text { undergoing PTCA }\end{array}$ & $\begin{array}{l}\text { diameter stenosis > } \\
50 \% \text { at FU }\end{array}$ & PTCA-STENT & No & 37 \\
\hline
\end{tabular}


Table I: Summary information of studies included in the meta-analyses. (Continued)

\begin{tabular}{|c|c|c|c|c|c|c|}
\hline \\
\hline $\begin{array}{l}\text { Wijpkema, 2006, } \\
\text { Netherlands [29] }\end{array}$ & $\begin{array}{l}\text { cohort } \\
9 \text { months }\end{array}$ & $\begin{array}{l}2888 \text { (2050/838), } \\
\text { Caucasians, } 62 \text { (I I), } \\
\text { CAD patients } \\
\text { undergoing elective } \\
\text { PTCA }\end{array}$ & $\begin{array}{l}\text { death from cardiac } \\
\text { causes, Ml } \\
\text { attributable to target } \\
\text { vessel and target } \\
\text { vessel } \\
\text { revascularization }\end{array}$ & PTCA-STENT & $\begin{array}{l}\text { Yes (AGT, AGTIR, } \\
\text { AGT2R, HMOXI) }\end{array}$ & 35 \\
\hline $\begin{array}{l}\text { Gomma, 2002, } \\
\text { UK [3I] }\end{array}$ & $\begin{array}{l}\text { cohort } \\
6 \text { months }\end{array}$ & $\begin{array}{l}205 \text { (155/50), } \\
\text { Caucasians, } 59.4 \text { (9.9), } \\
\text { CAD patients } \\
\text { undergoing PTCA }\end{array}$ & $\begin{array}{l}\text { diameter stenosis > } \\
50 \% \text { at FU }\end{array}$ & PTCA-STENT & No & 27 \\
\hline $\begin{array}{l}\text { Ruy, 2002, Korea } \\
\text { [32] }\end{array}$ & $\begin{array}{l}\text { cohort } \\
6 \text { months }\end{array}$ & $\begin{array}{l}238(178 / 60), \text { East } \\
\text { Asians, } 59.5(9.9), \text { CAD } \\
\text { patients undergoing } \\
\text { PTCA }\end{array}$ & $\begin{array}{l}\text { diameter stenosis > } \\
50 \% \text { at FU }\end{array}$ & PTCA-STENT & $\begin{array}{l}\text { Yes (CYPI I B2, } \\
A G T)\end{array}$ & 32 \\
\hline $\begin{array}{l}\text { Ribichini, 2004, } \\
\text { Italy [33] }\end{array}$ & $\begin{array}{l}\text { cohort } \\
6 \text { months }\end{array}$ & $\begin{array}{l}897 \text { (I60/737), } \\
\text { Caucasians, 6I (I0), } \\
\text { CAD patients } \\
\text { undergoing PTCA }\end{array}$ & $\begin{array}{l}\text { diameter stenosis > } \\
50 \% \text { at FU }\end{array}$ & PTCA-STENT & No & 33 \\
\hline $\begin{array}{l}\text { Taniguchi, 200I, } \\
\text { Japan [34] }\end{array}$ & $\begin{array}{l}\text { cohort } \\
6 \text { months }\end{array}$ & $\begin{array}{l}67(50 / 17) \text {, East Asians, } \\
65.2(9.7), \text { CAD } \\
\text { patients undergoing } \\
\text { PTCA }\end{array}$ & $\begin{array}{l}>50 \% \text { progression of } \\
\text { the residual stenosis } \\
\text { at FU }\end{array}$ & PTCA-STENT & No & 23 \\
\hline $\begin{array}{l}\text { Koch, 2000, } \\
\text { Germany [35] }\end{array}$ & $\begin{array}{l}\text { cohort } \\
\text { I year }\end{array}$ & $\begin{array}{l}\text { I850 (1458/392), } \\
\text { Caucasians, } 62.9(10), \\
\text { CAD patients } \\
\text { undergoing PTCA }\end{array}$ & $\begin{array}{l}\text { diameter stenosis > } \\
50 \% \text { at FU }\end{array}$ & PTCA-STENT & No & 40 \\
\hline $\begin{array}{l}\text { Gurlek, 2000, } \\
\text { Turkey [36] }\end{array}$ & $\begin{array}{l}\text { cohort } \\
6 \text { months }\end{array}$ & $\begin{array}{l}\text { I } 32 \text { (I I } 2 / 20) \text {, Turks, } 53 \\
\text { (9), CAD patients } \\
\text { undergoing PTCA }\end{array}$ & $\begin{array}{l}\text { diameter stenosis }> \\
50 \% \text { at FU }\end{array}$ & PTCA-STENT & No & 29 \\
\hline \multirow[t]{2}{*}{$\begin{array}{l}\text { Guneri, 2005, } \\
\text { Turkey [43] }\end{array}$} & $\begin{array}{l}\text { cohort } \\
9 \text { months (2.9) }\end{array}$ & $\begin{array}{l}94(59 / 35) \text {, Turks, } 59.6 \\
(9.9) \text {, CAD diabetic } \\
\text { patients undergoing } \\
\text { PTCA for stable angina } \\
\text { pectoris }\end{array}$ & $\begin{array}{l}\text { diameter stenosis > } \\
50 \% \text { at FU }\end{array}$ & PTCA-STENT & No & 26 \\
\hline & & & & $\begin{array}{l}\text { Angioplasty } \\
\text { with ACEi } \\
\text { treatment }\end{array}$ & & \\
\hline $\begin{array}{l}\text { Ribichini, 2003, } \\
\text { Italy [42] }\end{array}$ & $\begin{array}{l}\text { Cohort } \\
6.3(2.5) \text { months }\end{array}$ & $\begin{array}{l}27 \mathrm{I}(\mathrm{nr}), \text { Caucasians, } \\
6 \mathrm{I}(\mathrm{I0}), \mathrm{CAD} \text { patients } \\
\text { undergoing PTCA }\end{array}$ & $\begin{array}{l}\text { diameter stenosis > } \\
50 \% \text { at FU }\end{array}$ & $\begin{array}{l}\text { PTCA-STENT + } \\
\text { ACEi }\end{array}$ & No & 35 \\
\hline $\begin{array}{l}\text { Okamura, 1999, } \\
\text { Japan [44] }\end{array}$ & $\begin{array}{l}\text { cohort } \\
6 \text { months }\end{array}$ & $\begin{array}{l}97 \text { (84/I3), East Asians, } \\
60 \text { (2), CAD patients } \\
\text { undergoing PTCA for } \\
\text { stable angina pectoris }\end{array}$ & $\begin{array}{l}\text { diameter stenosis > } \\
50 \% \text { at FU }\end{array}$ & $\begin{array}{l}\text { PTCA-balloon + } \\
\text { Imidapril } 5 \text { mg }\end{array}$ & No & 29 \\
\hline $\begin{array}{l}\text { Okumura, 2002, } \\
\text { Japan [45] }\end{array}$ & $\begin{array}{l}\text { cohort } \\
6 \text { months }\end{array}$ & $\begin{array}{l}92(73 / 19), \text { East Asians, } \\
64.3(8.9), \text { CAD } \\
\text { patients undergoing } \\
\text { PTCA }\end{array}$ & $\begin{array}{l}\text { diameter stenosis > } \\
50 \% \text { at FU }\end{array}$ & $\begin{array}{l}\text { PTCA-STENT + } \\
\text { Quinapril } 18 \text { mg }\end{array}$ & No & 22 \\
\hline $\begin{array}{l}\text { Ferrari, 2002, } \\
\text { multicenter } \\
\text { (Europe) [46] }\end{array}$ & $\begin{array}{l}\text { cohort } \\
6 \text { months }\end{array}$ & $\begin{array}{l}\text { I54 (I I9/35), } \\
\text { Caucasians, 6I (9.9), } \\
\text { CAD patients } \\
\text { undergoing PTCA }\end{array}$ & $\begin{array}{l}>50 \% \text { progression of } \\
\text { the residual stenosis } \\
\text { at FU }\end{array}$ & $\begin{array}{l}\text { PTCA-STENT + } \\
\text { ACEi }\end{array}$ & No & 36 \\
\hline $\begin{array}{l}\text { Jorgensen, 200I, } \\
\text { Netherlands [49] }\end{array}$ & $\begin{array}{l}\text { cohort } \\
6 \text { months }\end{array}$ & $\begin{array}{l}369 \text { (293/76), } \\
\text { Caucasians, } 59 \text { (43-73), } \\
\text { CAD patients } \\
\text { undergoing PTCA for } \\
\text { stable angina }\end{array}$ & $\begin{array}{l}\text { diameter stenosis > } \\
50 \% \text { at FU }\end{array}$ & $\begin{array}{l}\text { PTCA-STENT + } \\
\text { ACEi }\end{array}$ & No & 40 \\
\hline
\end{tabular}

Abbreviations: DCA: directional coronary atherectomy, FU: follow-up, UA: unstable angina, MI: myocardial infarction, RCT: randomized controlled trial, ACEi: angiotensin converting enzyme inhibitors, nr: non-reported

given the known importance of anatomical factors, procedural factors and diabetes in determining the risk of restenosis, any genetic effect seems a priori likely to be small [77]. Despite the lack of high biological plausibility, several studies have examined the risk of restenosis in association with $A C E I / D$ polymorphism.
Overall 34 studies investigating restenosis were included (Table 1 and Additional file 1). Eleven studies used PTCA with balloon angioplasty alone (PTCA-balloon) [1726,37], 12 studies used PTCA with bare-metal stent deployment (PTCA-STENT) [29-36,43,45,46,49], nine studies used PTCA and investigated the effect of concom- 
itant administration of ACE inhibitors (ACEi) [42-50] and two studies used directional coronary atherectomy followed by PTCA $[51,52]$. The data from 28 studies [17$26,29-37,42-46,49]$ meeting the meta-analysis eligibility criteria were synthesized (Table 1). Since the biological phenomena underlying restenosis after PTCA-balloon and PTCA-STENT are distinct (negative remodeling due to elastic recoil versus neointimal hyperplasia and inflammatory response, respectively) [78], separate meta-analyses for PTCA-balloon (11 studies included: [17-26,37]) and PTCA-STENT $(12$ studies included: [29$36,43,45,46,49])$ were performed. Moreover, the interaction between PTCA and ACEi treatment was evaluated in the context of a third meta-analysis (five studies included: $[42,44-46,49])$. The findings of the studies not-included in the meta-analysis are presented in Additional file 1.

\section{Main results, subgroup and sensitivity analyses}

Table 2 and Figures 2a) and $2 \mathrm{~b}$ ) show the results for the association between ACE I/D gene polymorphism and the risk of restenosis after PTCA.

All studies investigating restenosis after PTCA-balloon were included in the meta-analysis. The main analysis for investigating the association between allele $D$ and the risk of restenosis after PTCA-balloon relative to the allele I, revealed significant heterogeneity $(\mathrm{p}<0.01)$ among studies and, the random effects pooled OR was significant (RE OR 1.34(1.09-1.65)). The recessive and dominant models also showed significant association $(\mathrm{RE} O \mathrm{OR}=$ $1.42(1.07-1.91)$ and $\mathrm{RE} \mathrm{OR}=1.36(1.05-1.76)$, respectively). The additive model produced significant association $(\mathrm{RE} \mathrm{OR}=1.42(1.07-1.91))$ and the co-dominant model non-significant association (RE OR $=0.95(0.79$ $1.15)$ ) as it was anticipated. Thus, ACE I/D polymorphism contributes to risk of restenosis under an additive model. In subgroup analysis by "race", Caucasians showed lack of significant heterogeneity $(\mathrm{pQ}=0.58)$ and a marginal significance for the allele contrast (FE OR $=1.16(1.02-$ 1.31)) whereas East Asians revealed significant heterogeneity among studies ( $\mathrm{pQ}<0.01)$ and non-significant association $(\mathrm{RE} \mathrm{OR}=1.85(0.90-3.83))$.

On the contrary, in the meta-analyses investigating the risk of restenosis after PTCA-STENT or after PTCA and treatment with ACEi, there was non-significant heterogeneity among studies $(\mathrm{pQ}>0.10)$ and the association was non-significant overall, for Whites and East Asians, under any genetic model.

Potential Bias. The cumulative meta-analysis of the allelic contrast for restenosis after PTCA-balloon showed a trend of association as information accumulates (Figure 3). In recursive cumulative meta-analysis, the relative change in RE OR stabilized after 1996/1995 indicating that there is sufficient evidence for supporting an association (Figure 4a). In contrast, analysis for restenosis after PTCA-STENT showed that the association remained non-significant for the whole period (Figure 3 ). In the recursive cumulative meta-analysis, the relative change in RE OR did not stabilize in a specific OR indicating the need of more evidence for investigating the association (Figure $4 \mathrm{~b}$ ). The subgroup analysis for study quality showed lack of significant heterogeneity $(\mathrm{pQ}=0.46)$ and produced non-significant association ( $\mathrm{FE} \mathrm{OR}=1.13(0.99-1.28)$ ) in the case of high-quality studies for PTCA-balloon. In contrast, low quality studies showed significant heterogeneity $(\mathrm{pQ}=$ 0.05 ) and significant association (RE OR $=1.99(1.48-$ 2.69)) (Table 2). For PTCA-STENT studies, the subgroup analysis by quality did not reveal any significant associations, though significant heterogeneity across low quality studies was observed ( $\mathrm{pQ}=0.08)$. The Egger test for the allele contrast indicated that there is differential magnitude of effect in large versus small studies $(\mathrm{p}<0.08)$.

\section{Coronary artery by-pass grafting}

Two small-scale studies $[53,54]$ investigated the risk of atherosclerotic degeneration in venous grafts in association with the ACE I/D polymorphism, but the reported results are discrepant (Additional file 1). In a European cohort of CAD patients treated with CABG, the ACE genotype was an independent predictor of total and cardiac mortality in two-year follow up, explaining $17.7 \%$ of cardiac events, although a relationship of $I / D$ polymorphism with graft atherosclerosis was not investigated [55].

\section{Conservative treatment strategies}

The results are summarized in Additional file 1.

\section{Anti-hypertensive therapy}

Two primary prevention trials of CAD assessed the effect of $A C E I / D$ on anti-hypertensive therapy and reported non-significant results overall $[57,58]$. The GenHAT study [57] found no differences for the primary endpoint of fatal CAD and nonfatal MI across gene-drug strata. ACE I/ $D$ polymorphism was found to be significant only in the subgroup of women treated with lisinopril. In the PROGRESS study that enrolled patients with history of cerebrovascular disease, there were no ACE-genotype specific benefits of perindopril administration on the outcome of fatal CAD and nonfatal MI [58]. A retrospective study by Marciante et al. [59] was the first study to examine the role of haplotypic variation in ACE gene on primary prevention of MI. None of the examined $A C E$ haplotypes (capturing the $I / D$ polymorphism) was associated with the risk of MI in pharmacologically treated hypertensive patients. The effect of ACE I/D polymorphism and ACEi treatment on surrogate CAD outcomes was investigated by eight studies [60-67] (Additional file $1)$. The reported results are diverse and inconsistent, 
Table 2: Odds ratios and heterogeneity results for the genetic contrasts of ACE IID gene polymorphism for restenosis a) after PTCAballoon, b) after PTCA-STENT, and c) after PTCA and treatment with ACE inhibitors.

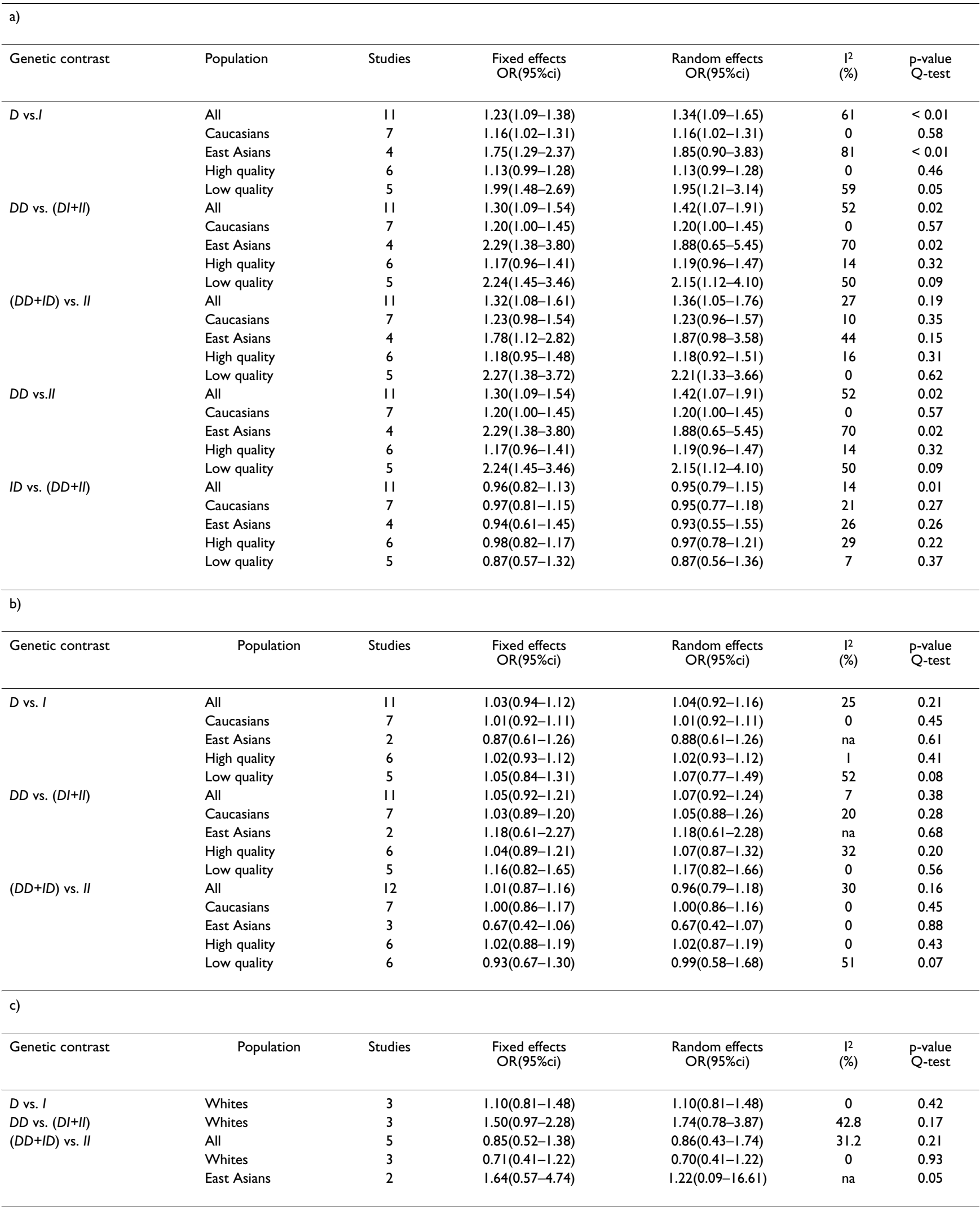


derived mainly from underpowered or non-randomised studies.

\section{Lipid lowering treatment}

Regarding clinical outcomes, three randomized trials failed to show any significant ACE genotype-statin treatment interactions in primary [68] or secondary prevention [70,71] of CAD (Additional file 1). Additionally, in the observational Rotterdam study, non-significant associations were reported overall, although a significant interaction between the ACE gene and the use of statins was observed in male participants [69]. Regarding the angiographic assessment of CAD progression or regression after statin treatment, the ACE I/D genotype was found to be a major modifier, with $D D$ patients being more likely to have definite regression of coronary lesions, consistent with a greater reduction in low density lipoprotein cholesterol levels [71].

\section{Cardiac rehabilitation}

Two studies examined the role of ACE I/D polymorphism in modifying the response of physical training in aerobic and exercise capacity in CAD patients. Defoor et al. [73] found a greater beneficial effect in patients with II genotype than in $D$ allele carriers, while Iwanaga et al. [74] reported no significant findings in their smaller study.

\section{Discussion}

In this review, we have explored a large and varied literature and have found a wide range of quality of evidence. The studies reviewed offer inconclusive and in many cases contradictory results. The most widely investigated outcome was the restenosis post-PTCA. We conducted metaanalyses to shed some light on the contradictory results, as well as to decrease the uncertainty of the effect size of estimated risk.

The risk of restenosis following PTCA-balloon was consistent for the allele contrast, the recessive, the dominant and additive models, though the results showed significant heterogeneity. Heterogeneity may result from differences in sample selection (e.g., in age-at-onset, gender, or diagnostic criteria), in genotyping methodology (two different genotyping procedures were used), or may be due to real differences in populations (e.g., 'racial' descent) or due to interactions with other unknown risk factors [14].

The results of the meta-analysis were affected by population origin. Caucasians showed significance under the allele contrast whereas East Asians produced non-significant results. The lower frequency of the $D D$ genotype in East Asian populations, coupled with the small sample size in most studies, imply that any negative conclusion could be due to low statistical power. True race-specific genetic effects could explain this pattern of results, since functional analyses of variation in ACE gene have indicated that different loci control ACE levels in particular 'racial' groups [79]. Nevertheless, any inconsistencies in risk effects of ACE I/D on restenosis between Caucasian and East Asians might be also due to race-related anatomical differences of coronary arteries, since a smaller total vessel diameter has been described for Asian populations [80].

The need for cumulative and recursive cumulative metaanalyses has already been highlighted [6]. The stability in the relative changes in ORs indicates that there is enough evidence to draw safe conclusions about the modifying effect of ACE I/D polymorphism in restenosis post-PTCA. However, the results of the subgroup analysis by quality $[6,81]$ make the robustness of the main analysis questionable.

Regarding the ACE I/D polymorphism and the risk of restenosis after PTCA-STENT or after PTCA and treatment with ACEi, there was non-significant heterogeneity among studies and the association was non-significant overall and for all examined subgroups, under any genetic model. Despite higher biological plausibility in the context of the PTCA-STENT intervention (the renin-angiotensin-aldosterone system is considered to be more implicated in the inflammatory processes of neointimal growth underlying post-PTCA-STENT restenosis, rather than in elastic recoil remodeling following PTCA-balloon) [78], the ACE polymorphism was not associated with higher restenosis risk. The instability of the RE OR in the recursive cumulative meta-analysis indicated the need of more evidence to draw safer conclusions.

Our analysis showed a differential magnitude of effect in large versus small studies. Previous meta-analyses had already highlighted that the pooled estimate based on published literature, which favoured an association, was probably distorted by publication bias toward positive results $[7,8]$. However, our analysis was based on a substantially larger number of studies (including a total of 9945 patients vs 4631 and 3150 patients that were used in previous meta-analyses $[7,8]$, respectively), which allowed investigation of $A C E I / D$ and angioplasty interaction in the context of three clinically relevant distinct meta-analyses. The ACE I/D polymorphism was associated only with restenosis post-PTCA-balloon and contrary to previous findings [8], the results for this association showed significant heterogeneity. Our subgroup analysis identified ethnicity as a potential factor contributing to heterogeneity and highlighted the effect of study quality on summary estimates, which had not been previously addressed. Additionally, the studies on the ACE I/D and restenosis following PTCA-STENT were not significantly heterogeneous, contradicting previous findings [8], 
Ohishi, 1993 [26]

Kamitani, 1995 [20]

Samani, 1996 [21]

van Bockxmeer, 1995 [22]

Beohar, 1995 [24]

Kaski, 1996 [19]

Tsukada, 1997 [23]

Hamon, 1998 [37]

Yoshida, 1999 [18]

Volzke, 2000 [17]

Zee, 2001 [25]

Pooled

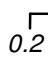

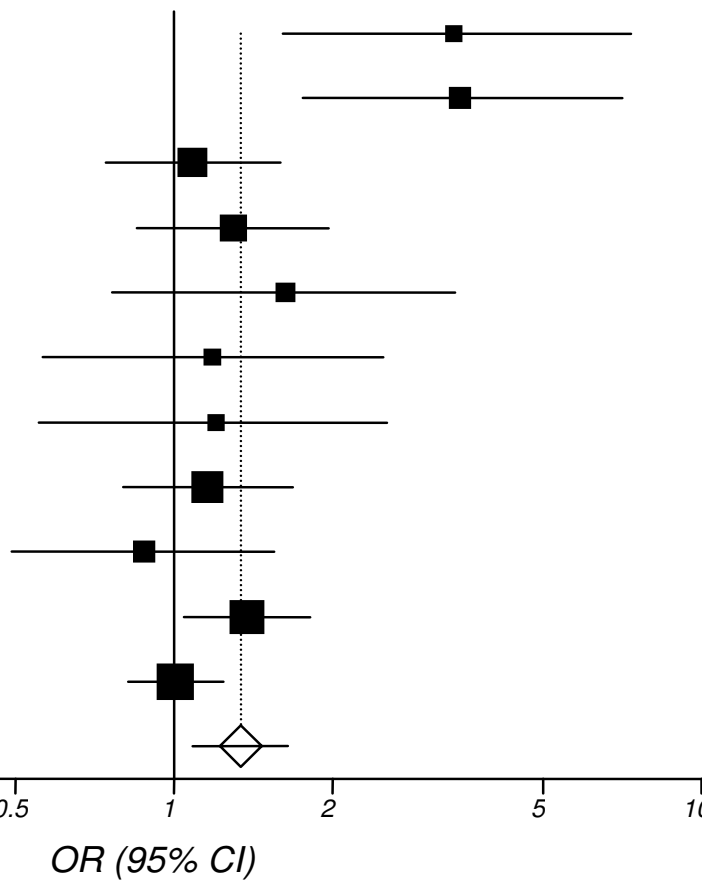

$3.40(1.61,7.36)$

$3.49(1.75,7.05)$

$1.09(0.74,1.59)$

$1.29(0.85,1.97)$

$1.63(0.76,3.42)$

$1.18(0.56,2.49)$

$1.20(0.55,2.53)$

$1.16(0.80,1.68)$

$0.88(0.49,1.55)$

$1.37(1.04,1.81)$

$1.01(0.82,1.24)$

$1.34(1.09,1.65)$
Amant, 1997 [30]

Koch, 2000 [35]

Gurlek, 2000 [36]

Taniguchi, 2001 [34]

Jorgensen, 2001 [49]

Gomma, 2002 [31]

Ruy, 2002 [32]

Ferrari, $2002[46]$

Ribichini, 2004 [33]

Guneri, 2005 [43]

Wijpkema, 2006 [29]

Pooled

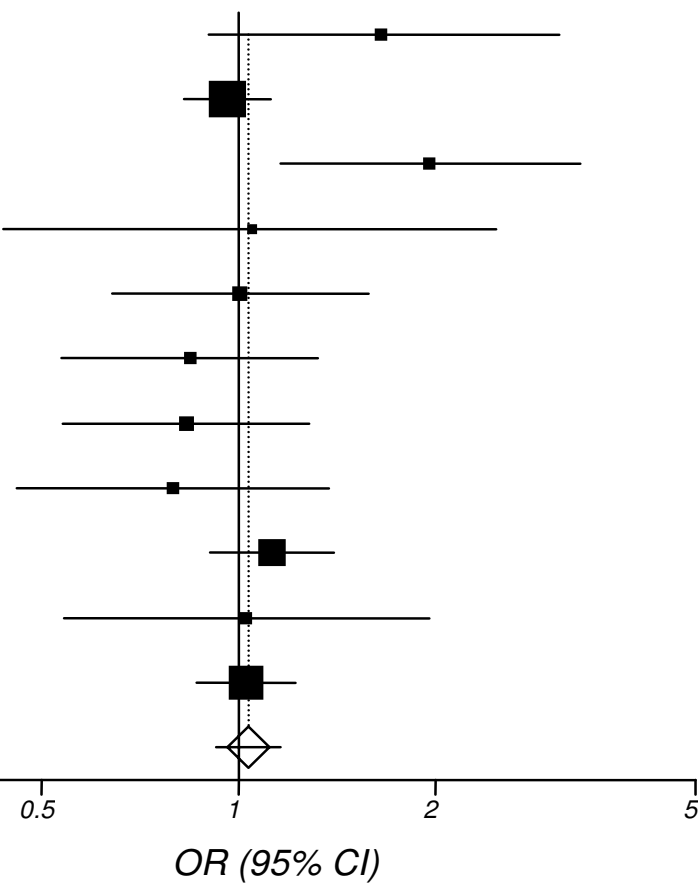

$1.65(0.90,3.10)$

$0.96(0.82,1.12)$

$1.96(1.16,3.33)$

$1.05(0.44,2.48)$

$1.00(0.64,1.58)$

$0.84(0.54,1.32)$

$0.83(0.54,1.28)$

$0.79(0.46,1.38)$

$1.12(0.90,1.40)$

$1.03(0.54,1.96)$

$1.03(0.86,1.22)$

$1.04(0.92,1.16)$

\section{Figure 2}

Random effects (RE) odds ratio (OR) estimates with the corresponding $95 \%$ confidence interval (CI) of the allele contrast (ACE D vs. I) for restenosis a) after PTCA-balloon, and b) after PTCA-STENT. The OR estimate of each study is marked with a solid black square. The size of the square represents the weight that the corresponding study exerts in the meta-analysis. The confidence intervals of pooled estimates are displayed as a horizontal line through the diamond. The horizontal axis is plotted on a log scale. 


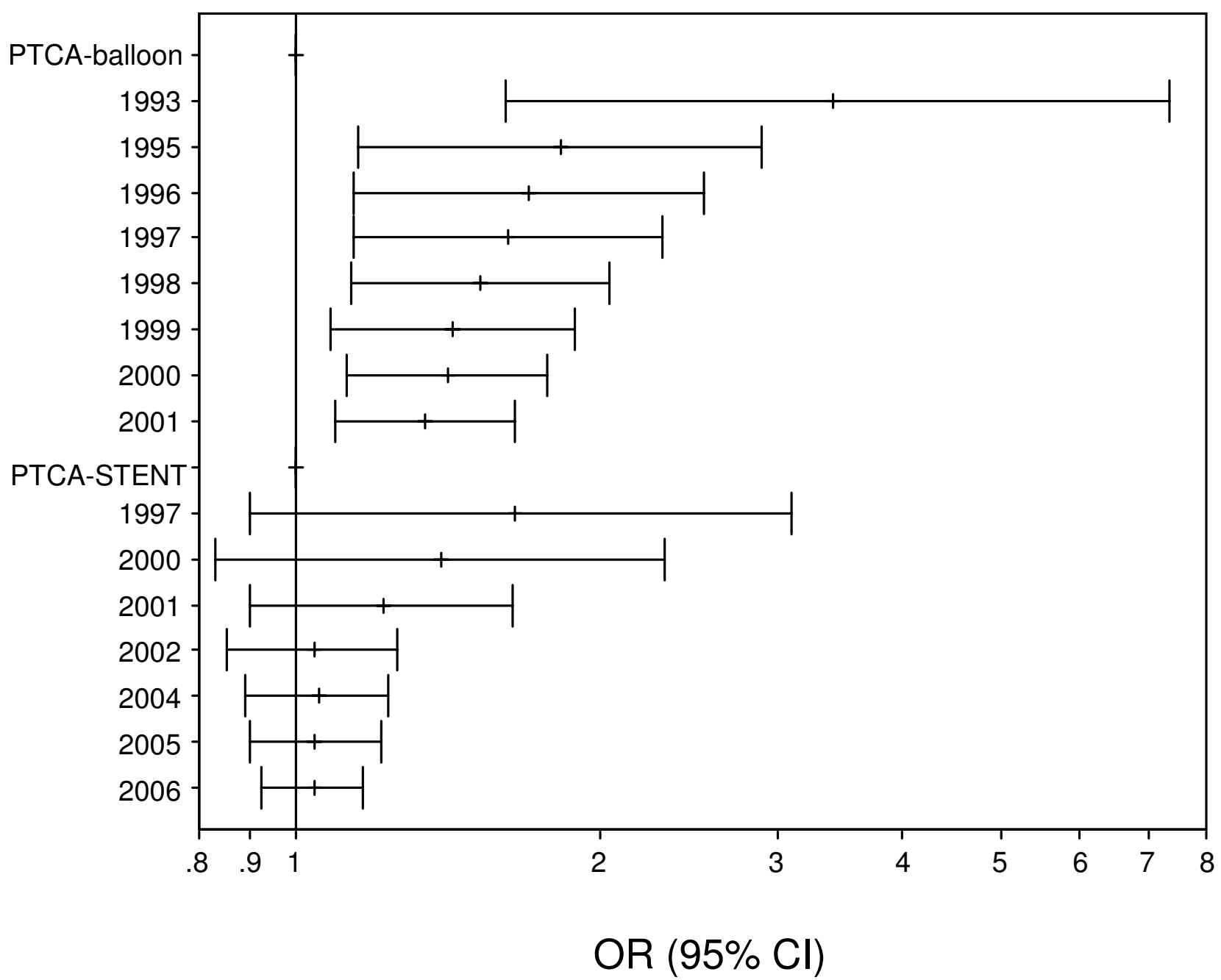

Figure 3

Cumulative meta-analysis of the allele contrast (ACE D vs. I) for restenosis a) after PTCA-balloon, and b) after PTCA-STENT. The random effects pooled odds ratio (OR) with the corresponding $95 \%$ confidence interval $(\mathrm{Cl})$ at the end of each year-information step is shown.

although the instability of the RE OR in the recursive cumulative meta-analysis indicated that this potential association remains an unresolved issue.

All of the analyzed studies in the meta-analysis for PTCASTENT involved bare metal stents. Given the near-universal adoption of stenting as the default strategy for PTCA, the ACE I/D polymorphism can not be considered as a reliable genetic marker of restenosis after PTCA. Nevertheless, in the era of drug-eluting stents [82], late stent thrombosis emerges as a clinically important outcome that probably merits at least equivalent attention to restenosis in the design of future studies.
The treatment modalities in which ACE gene has been investigated as a potential modifier gene are diverse and not linked by common molecular mechanisms, thus questioning the biological rationale underlying the selection of this candidate gene. The discrepancy of the observed results regarding the clinical and surrogate outcomes of the other interventions (Additional file 1) could be due to a series of factors, including heterogeneity of enrolled cases, outcome definition variability, genotyping errors [16], limited statistical power, different study designs and variable interventions (in terms of type, dose, duration or timing). Downgrading the potential significance of ACE I/D polymorphism in the pharmacogenetics 

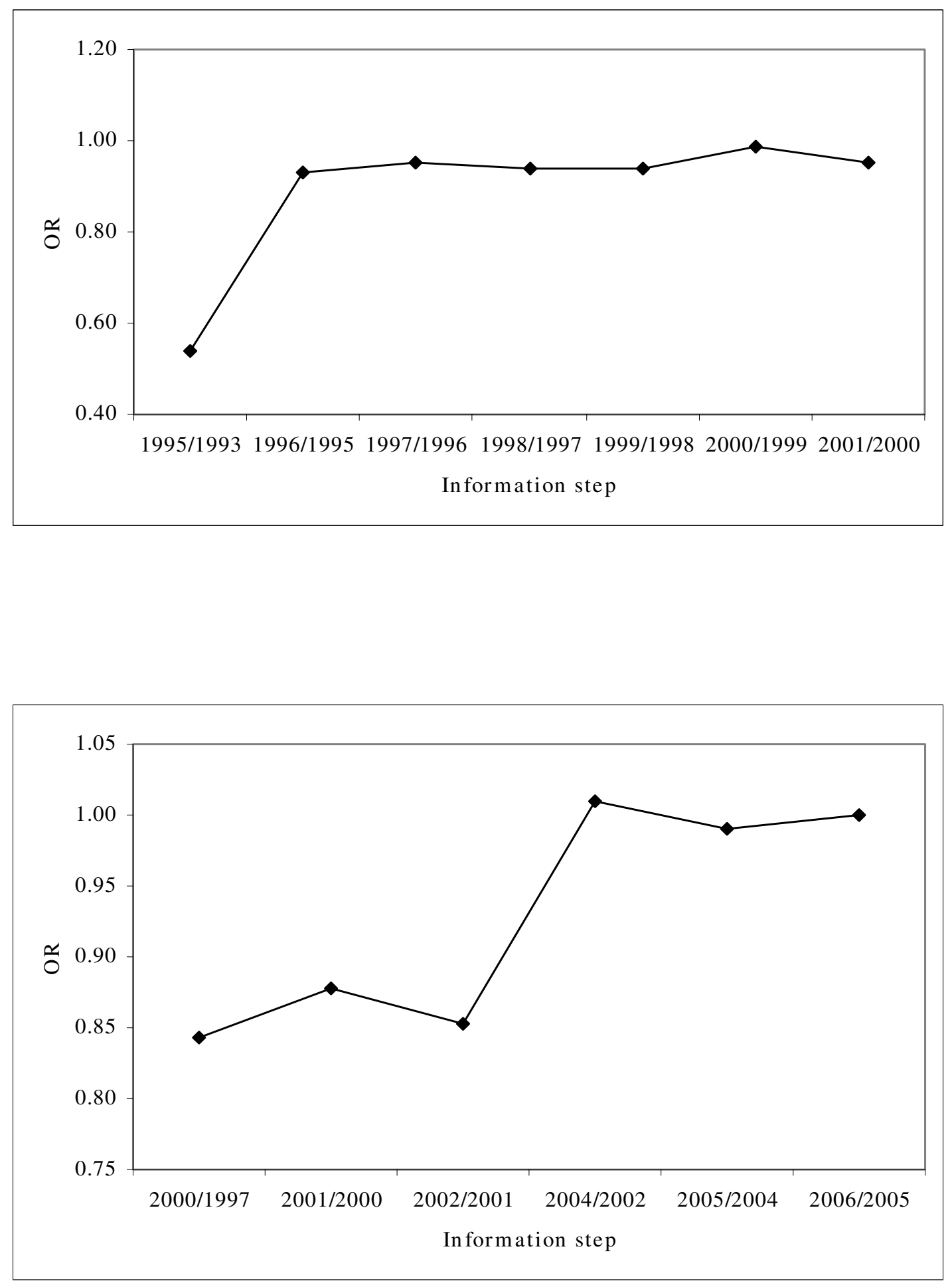

\section{Figure 4}

Recursive cumulative meta-analysis of the allele contrast (ACE D vs. I) for restenosis a) after PTCA-balloon, and b) after PTCA-STENT. The relative change in random effects pooled odds ratio (OR) in each information step (OR in next year/OR in current year) for the allele contrast is shown. 
of CAD, none of the six studies enrolling more than 1,000 individuals $[29,35,40,57,58,68]$ reported significant results on its respective outcomes.

Large, prospective studies with similar study designs, detailed clinical records, standardised outcome definitions, limited variability in subjects enrolled and interventions used, are needed. Moreover, if researchers can make their data on individual patients readily available, adjusted estimates for the effects of modifiers (such as age or gender) can also be analyzed.

Since the ACE I/D polymorphism is intronic, it is unlikely that it is functional. Despite considerable effort, the precise location of the functional polymorphism, or polymorphisms, is still unknown [83]. Future studies utilizing the HapMap tagging SNPs data, could provide useful insights, regarding the disease-associated gene haplotypes. So far, only one study [59] used the haplotype approach reporting negative results. In addition, the effect of epistatic loci interacting with $A C E I / D$ remains a poorly investigated issue [7]. Elucidating the modifying effect of the renin-angiotensin-aldosterone system on response to treatment to CAD would demand a multigene haplotype approach searching for variation throughout this pathophysiological pathway [84]. With the advent of 'agnostic' genome-wide association studies, novel variants of unprecedented biological suspicion can be unravelled by properly designed and well-powered pharmacogenomic studies [85].

Cost-effectiveness analyses are crucial inputs in pharmacogenetic studies prior implementation of genetic tests in clinical practice [86]. Despite some promising initial pharmacoeconomic investigations [87], the ACE I/D genotype and treatment interactions in CAD are not reproducible and convincing enough to justify clinical implementation any time soon.

\section{Conclusion}

Many studies have tried to characterize the effects of $A C E$ $I / D$ polymorphism on the response to treatment in CAD, in the context of both interventional and conservative therapeutic options for clinical and surrogate endpoints. However, the reported results so far are discrepant and inconsistent. In view of available evidence, genetic testing of ACE I/D polymorphism prior to clinical decision making is not currently justified. The relation between $A C E$ genetic variation and response to treatment in CAD remains an unresolved issue. The results of long-term and properly designed prospective studies hold the promise for pharmacogenetically tailored therapy in CAD.

\section{Abbreviations}

All abbreviations are defined in the text.

\section{Competing interests}

Georgios Kitsios is Pfizer-Tufts Medical Center Research Fellow in Clinical Research.

\section{Authors' contributions}

GK and EZ designed the study and drafted the manuscript. GK and EZ extracted the data and EZ analyzed the data. Both authors had equal contribution to the revised manuscript.

\section{Additional material}

\section{Additional file 1}

Summary information of studies not included in the meta-analyses. The data provided represent the extracted information from studies not considered in the meta-analyses.

Click here for file

[http://www.biomedcentral.com/content/supplementary/14712350-10-50-S1.doc]

\section{Acknowledgements}

Scientific support for this project was provided through the Tufts Clinical and Translational Science Institute (Tufts CTSI) under funding from the National Institute of Health/National Center for Research Resources (ULI RR025752). Points of view or opinions in this paper are those of the authors and do not necessarily represent the official position or policies of the Tufts CTSI.

\section{References}

I. Arnett DK, Baird AE, Barkley RA, Basson CT, Boerwinkle E, Ganesh SK, Herrington DM, Hong Y, Jaquish C, McDermott DA, O'Donnell C], American Heart Association Council on Epidemiology and Prevention; American Heart Association Stroke Council; Functional Genomics and Translational Biology Interdisciplinary Working Group: Relevance of genetics and genomics for prevention and treatment of cardiovascular disease: a scientific statement from the American Heart Association Council on Epidemiology and Prevention, the Stroke Council, and the Functional Genomics and Translational Biology Interdisciplinary Working Group. Circulation 2007, I I 5:2878-290 I.

2. Zintzaras E, Kitsios G: Identification of chromosomal regions linked to premature myocardial infarction: a meta-analysis of whole-genome searches. J Hum Genet 2006, 5 I:1015-1021.

3. Damani SB, Topol EJ: Future use of genomics in coronary artery disease. J Am Coll Cardiol 2007, 50:1933-1940.

4. Unal B, Critchley JA, Capewell S: Explaining the decline in coronary heart disease mortality in England and Wales between I98I and 2000. Circulation 2004, 109: I I01-I I07.

5. Johnson JA, Cavallari LH: Cardiovascular pharmacogenomics. Exp Physiol 2005, 90:283-289.

6. Zintzaras E, Raman G, Kitsios G, Lau J: Angiotensin-converting enzyme insertion/deletion gene polymorphic variant as a marker of coronary artery disease: a meta-analysis. Arch Intern Med 2008, 168:1077-1089.

7. Bonnici F, Keavney B, Collins R, Danesh J: Angiotensin converting enzyme insertion or deletion polymorphism and coronary restenosis: meta-analysis of 16 studies. BMJ 2002, 325:5 I 7-520.

8. Agema WR, Jukema JW, Zwinderman AH, Wall EE van der: A metaanalysis of the angiotensin-converting enzyme gene polymorphism and restenosis after percutaneous transluminal coronary revascularization: evidence for publication bias. Am Heart J 2002, I 44:760-768.

9. Danser AH, Schalekamp MA, Bax WA, Brink AM van den, Saxena PR, Riegger GA, Schunkert H: Angiotensin-converting enzyme in 
the human heart. Effect of the deletion/insertion polymorphism. Circulation 1995, 92:1387-1388.

10. Anderson JL, Adams CD, Antman EM, Bridges CR, Califf RM, Casey DE Jr, Chavey WE 2nd, Fesmire FM, Hochman JS, Levin TN, Lincoff AM, Peterson ED, Theroux P, Wenger NK, Wright RS, Smith SC Jr, Jacobs AK, Adams CD, Anderson JL, Antman EM, Halperin JL, Hunt SA, Krumholz HM, Kushner FG, Lytle BW, Nishimura R, Ornato JP, Page RL, Riegel B, American College of Cardiology; American Heart Association Task Force on Practice Guidelines (Writing Committee to Revise the 2002 Guidelines for the Management of Patients With Unstable Angina/Non-ST-Elevation Myocardial Infarction); American College of Emergency Physicians; Society for Cardiovascular Angiography and Interventions; Society of Thoracic Surgeons; American Association of Cardiovascular and Pulmonary Rehabilitation; Society for Academic Emergency Medicine: ACC/AHA 2007 guidelines for the management of patients with unstable angina/non ST-elevation myocardial infarction: a report of the American College of Cardiology/American Heart Association Task Force on Practice Guidelines (Writing Committee to Revise the 2002 Guidelines for the Management of Patients With Unstable Angina/Non ST-Elevation Myocardial Infarction): developed in collaboration with the American College of Emergency Physicians, the Society for Cardiovascular Angiography and Interventions, and the Society of Thoracic Surgeons: endorsed by the American Association of Cardiovascular and Pulmonary Rehabilitation and the Society for Academic Emergency Medicine. Circulation 2007, I I6:el 48-e304.

II. Antman EM, Hand M, Armstrong PW, Bates ER, Green LA, Halasyamani LK, Hochman JS, Krumholz HM, Lamas GA, Mullany CJ, Pearle DL, Sloan MA, Smith SC Jr, 2004 Writing Committee Members, Anbe DT, Kushner FG, Ornato JP, Jacobs AK, Adams CD, Anderson JL, Buller CE, Creager MA, Ettinger SM, Halperin JL, Hunt SA, Lytle BW, Nishimura R, Page RL, Riegel B, Tarkington LG, Yancy CW: 2007 Focused Update of the ACC/AHA 2004 Guidelines for the Management of Patients With ST-Elevation Myocardial Infarction: a report of the American College of Cardiologyl American Heart Association Task Force on Practice Guidelines: developed in collaboration With the Canadian Cardiovascular Society endorsed by the American Academy of Family Physicians: 2007 Writing Group to Review New Evidence and Update the ACC/AHA 2004 Guidelines for the Management of Patients With ST-Elevation Myocardial Infarction, Writing on Behalf of the 2004 Writing Committee. Circulation 2008, II 7:296-329.

12. Fraker TD Jr, Fihn SD, Gibbons RJ, Abrams J, Chatterjee K, Daley J, Deedwania PC, Douglas JS, Ferguson TB Jr, Fihn SD, Fraker TD Jr, Gardin JM, O'Rourke RA, Williams SV, Smith SC Jr, Jacobs AK, Adams $C D$, Anderson JL, Buller CE, Creager MA, Ettinger SM, Halperin JL, Hunt SA, Krumholz HM, Kushner FG, Lytle BW, Nishimura R, Page RL, Riegel B, Tarkington LG, Yancy CW, American College of Cardiology; American Heart Association; American College of Cardiology/ American Heart Association Task Force on Practice Guidelines Writing Group: 2007 chronic angina focused update of the ACCl AHA 2002 Guidelines for the management of patients with chronic stable angina: a report of the American College of Cardiology/American Heart Association Task Force on Practice Guidelines Writing Group to develop the focused update of the 2002 Guidelines for the management of patients with chronic stable angina. Circulation 2007, I 1 6:2762-2772.

13. Fourth Joint Task Force of the European Society of Cardiology and Other Societies on Cardiovascular Disease Prevention in Clinical Practice (Constituted by representatives of nine societies and by invited experts, Graham I, Atar D, Borch-Johnsen K, Boysen G, Burell G, Cifkova R, Dallongeville J, De Backer G, Ebrahim S, Gjelsvik B, Herrmann-Lingen C, Hoes A, Humphries S, Knapton M, Perk J, Priori SG, Pyorala K, Reiner Z, Ruilope L, Sans-Menendez S, Scholte op Reimer W, Weissberg P, Wood D, Yarnell J, Zamorano JL, Other experts who contributed to parts of the guidelines:, Walma E, Fitzgerald $T$, Cooney MT, Dudina A, European Society of Cardiology (ESC) Committee for Practice Guidelines (CPG), Vahanian A, Camm J, De Caterina R, Dean V, Dickstein K, Funck-Brentano C, Filippatos G, Hellemans I, Kristensen SD, McGregor K, Sechtem U, Silber S, Tendera M, Widimsky P, Zamorano JL, Hellemans I, Altiner A, Bonora E, Durrington PN, Fagard R, Giampaoli S, Hemingway H, Hakansson J,
Kjeldsen SE, Larsen ML, Mancia G, Manolis AJ, Orth-Gomer K, Pedersen T, Rayner M, Ryden L, Sammut M, Schneiderman N, Stalenhoef AF, Tokgözoglu L, Wiklund O, Zampelas A: European guidelines on cardiovascular disease prevention in clinical practice: executive summary. Eur Heart J 2007, 28:2375-24I4.

14. Zintzaras E, Lau J: Synthesis of genetic association studies for pertinent gene-disease associations requires appropriate methodological and statistical approaches. J Clin Epidemiol 2008, $61: 634-645$.

15. Sterne JA, Egger M: Funnel plots for detecting bias in metaanalysis: guidelines on choice of axis. J Clin Epidemiol 2001, 54:1046-1055.

16. Shanmugam V, Sell KW, Saha BK: Mistyping ACE heterozygotes. PCR Methods Appl 1993, 3:120-121.

17. Volzke H, Hertwig S, Rettig R, Motz W: The angiotensinogen gene 235T variant is associated with an increased risk of restenosis after percutaneous transluminal coronary angioplasty. Clin Sci (Lond) 2000, 99:19-25.

18. Yoshida M, Iwai N, Ohmichi N, Izumi M, Nakamura Y, Kinoshita M: D allele of the angiotensin-converting enzyme gene is a risk factor for secondary cardiac events after myocardial infarction. Int J Cardiol 1999, 70: I 19-125.

19. Kasi JC, Zhang Y, Calvino R, Vazquez-Rodriguez JM, Castro-Beiras A, Jeffery S, Carter N: Angiotensin-converting enzyme insertion/ deletion polymorphism and restenosis after coronary angioplasty in unstable angina pectoris. Am J Cardiol 1996, 77:875-877.

20. Kamitani A, Rakugi H, Higaki J, Ohishi M, Shi SJ, Takami S, Nakata Y, Higashino Y, Fujii K, Mikami H: Enhanced predictability of myocardial infarction in Japanese by combined genotype analysis. Hypertension 1995, 25:950-953.

21. Samani NJ, O'Toole L, Martin D, Rai H, Fletcher S, Lodwick D, Thompson JR, Morice AH, Channer K, Woods KL: Insertion/deletion polymorphism in the angiotensin-converting enzyme gene and risk of and prognosis after myocardial infarction. J Am Coll Cardiol 1996, 28:338-344.

22. van Bockxmeer FM, Mamotte CD, Gibbons FA, Burke V, Taylor RR: Angiotensin-converting enzyme and apolipoprotein $E$ genotypes and restenosis after coronary angioplasty. Circulation 1995, 92:2066-207|.

23. Tsukada K, Ishimitsu T, Tsuchiya N, Horinaka S, Matsuoka H: Angiotensin-converting enzyme gene polymorphism and cardiovascular endocrine system in coronary angiography patients. Jpn Heart J 1997, 38:799-810.

24. Beohar N, Damaraju S, Prather A, Yu OT, Raizner A, Kleiman NS, Roberts R, Marian AJ: Angiotensin-I converting enzyme genotype DD is a risk factor for coronary artery disease. J Investig Med 1995, 43:275-280.

25. Zee RY, Fernandez-Ortiz A, Macaya C, Pintor E, Lindpaintner K, Fernandez-Cruz A: Ace D/l polymorphism and incidence of post-PTCA restenosis: a prospective, angiography-based evaluation. Hypertension 200I, 37:85I-855.

26. Ohishi M, Fujii K, Minamino T, Higaki J, Kamitani A, Rakugi $H$, Zhao $\mathrm{Y}$, Mikami $\mathrm{H}$, Miki T, Ogihara T: A potent genetic risk factor for restenosis. Nat Genet 1993, 5:324-325.

27. Hertwig S, Volzke H, Robinson DM, Motz W, Rettig R: Angiotensinogen M235T gene polymorphism and recurrent restenosis after repeated percutaneous transluminal coronary angiography. Clin Sci (Lond) 2002, I03:I0I-I06.

28. Mulder HJ, van Geel PP, Schalij MJ, van Gilst WH, Zwinderman AH, Bruschke AV: DD ACE gene polymorphism is associated with increased coronary artery endothelial dysfunction: the PREFACE trial. Heart 2003, 89:557-558.

29. Wijpkema JS, van Haelst PL, Monraats PS, Bruinenberg M, Zwinderman AH, Zijlstra F, Steege G van der, de Winter RJ, Doevendans PA, Waltenberger J, Jukema JW, Tio RA: Restenosis after percutaneous coronary intervention is associated with the angiotensinII type-I receptor II66A/C polymorphism but not with polymorphisms of angiotensin-converting enzyme, angiotensinII receptor, angiotensinogen or heme oxygenase-I. Pharmacogenet Genomics 2006, 16:331-337.

30. Amant C, Bauters C, Bodart JC, Lablanche JM, Grollier G, Danchin N, Hamon M, Richard F, Helbecque N, McFadden EP, Amouyel P, Bertrand ME: $\mathbf{D}$ allele of the angiotensin l-converting enzyme is a major risk factor for restenosis after coronary stenting. Circulation 1997, 96:56-60. 
31. Gomma AH, Elrayess MA, Knight C], Hawe E, Fox KM, Humphries SE: The endothelial nitric oxide synthase (Glu298Asp and 786 T\&gt;C) gene polymorphisms are associated with coronary in-stent restenosis. Eur Heart J 2002, 23: I 955- 1962

32. Ryu SK, Cho EY, Park HY, Im EK, Jang YS, Shin GJ, Shim WH, Cho SY: Renin-angiotensin-aldosterone system (RAAS) gene polymorphism as a risk factor of coronary in-stent restenosis. Yonsei MedJ 2002, 43:46I-472.

33. Ribichini F, Ferrero V, Matullo G, Feola M, Vado A, Camilla T, Guarrera S, Carturan S, Vassanelli C, Uslenghi E, Piazza A: Association study of the I/D polymorphism and plasma angiotensin-converting enzyme (ACE) as risk factors for stent restenosis. Clin Sci (Lond) 2004, I 07:38I-389.

34. Taniguchi I, Yamazaki T, Wagatsuma K, Kurusu T, Shimazu Y, Takikawa K, Yoshikawa M, Kageyama S, Mochizuki S: The DD genotype of angiotensin converting enzyme polymorphism is a risk factor for coronary artery disease and coronary stent restenosis in Japanese patients. Jpn Circ J 200I, 65:897-900.

35. Koch W, Kastrati A, Mehilli J, Bottiger C, von BN, Schomig A: Insertion/deletion polymorphism of the angiotensin I-converting enzyme gene is not associated with restenosis after coronary stent placement. Circulation 2000, I 02:197-202.

36. Gurlek A, Gulec S, Karabulut H, Bokesoy I, Tutar E, Pamir G, Alpman A, Toydemir R, Aras O, Oral D: Relation between the insertion/ deletion polymorphism of the angiotensin I converting enzyme gene and restenosis after coronary stenting. J Cardiovasc Risk 2000, 7:403-407.

37. Hamon M, Amant C, Bauters C, Richard F, Helbecque N, Passard F, McFadden EP, Lablanche JM, Bertrand ME, Amouyel P: Dual determination of angiotensin-converting enzyme and angiotensinII type I receptor genotypes as predictors of restenosis after coronary angioplasty. Am J Cardiol 1998, 8 I:79-8I.

38. Hamon M, Amant C, Bauters C, Lablanche JM, Bertrand M, Amouyel $P$ : ACE polymorphism, a genetic predictor of occlusion after coronary angioplasty. Am J Cardiol 1996, 78:679-68I.

39. Gross CM, Perrot A, Geier C, Posch MG, Hassfeld S, Kramer J, Schmidt S, Derer W, Dietz R, Ozcelik C: Recurrent in-stent restenosis is not associated with the angiotensin-converting enzyme D/I, angiotensinogen ThrI74Met and Met235Thr, and the angiotensin-II receptor I AI I 66C polymorphism. J Invasive Cardiol 2007, 19:26I-264.

40. Hamon M, Fradin S, Denizet A, Filippi-Codaccioni E, Grollier G, Morello R: Prospective evaluation of the effect of an angiotensin I converting enzyme gene polymorphism on the long term risk of major adverse cardiac events after percutaneous coronary intervention. Heart 2003, 89:32।-325.

41. Prisco D, Fatini C, Battaglini B, Gensini F, Fedi S, Falai M, Chioccioli M, Gori AM, Margheri M, Gensini GF: Angiotensin converting enzyme DD genotype affects the changes of plasma plasminogen activator inhibitor-I activity after primary percutaneous transluminal coronary angioplasty in acute myocardial infarction patients. Int J Clin Lab Res 2000, 30:179-185.

42. Ribichini F, Wijns W, Ferrero V, Matullo G, Camilla T, Feola M, Guarrera $S$, Vado $A$, Piazza $A$, Uslenghi $E$ : Effect of angiotensin-converting enzyme inhibition on restenosis after coronary stenting. Am J Cardiol 2003, 9 I: I54-I58.

43. Guneri S, Baris N, Aytekin D, Akdeniz B, Pekel N, Bozdemir V: The relationship between angiotensin converting enzyme gene polymorphism, coronary artery disease, and stent restenosis: the role of angiotensin converting enzyme inhibitors in stent restenosis in patients with diabetes mellitus. Int Heart J 2005, 46:889-897.

44. Okamura A, Ohishi M, Rakugi H, Katsuya T, Yanagitani Y, Takiuchi S, Taniyama Y, Moriguchi K, Ito H, Higashino Y, Fujii K, Higaki J, Ogihara $\mathrm{T}$ : Pharmacogenetic analysis of the effect of angiotensin-converting enzyme inhibitor on restenosis after percutaneous transluminal coronary angioplasty. Angiology 1999, 50:81 I-822.

45. Okumura K, Sone T, Kondo J, Tsuboi H, Mukawa H, Tsuzuki M, Imai $H$, Kamiya H, Mabuchi Y, Matsui H, Hayakawa T: Quinapril prevents restenosis after coronary stenting in patients with angiotensin-converting enzyme D allele. Circ J 2002, 66:311-316

46. Ferrari M, Mudra H, Grip L, Voudris V, Schachinger V, de Jaegere $P$, Rieber J, Hausmann D, Rothman M, Koschyk DH, Figulla HR, OPTICUS ACE Substudy: Angiotensin-converting enzyme insertion/ deletion polymorphism does not influence the restenosis rate after coronary stent implantation. Cardiology 2002, 97:29-36.

47. Koch W, Mehilli J, von BN, Bottiger C, Schomig A, Kastrati A: Angiotensin l-converting enzyme (ACE) inhibitors and restenosis after coronary artery stenting in patients with the DD genotype of the ACE gene. J Am Coll Cardiol 2003, 41:1957-1961.

48. Meurice T, Bauters C, Hermant X, Codron V, VanBelle E, Mc Fadden EP, Lablanche J, Bertrand ME, Amouyel P: Effect of ACE inhibitors on angiographic restenosis after coronary stenting (PARIS): a randomised, double-blind, placebo-controlled trial. Lancet 2001, 357:132|-1324.

49. Jorgensen E, Kelbaek H, Helqvist S, Jensen GV, Saunamaki K, Kastrup J, Havndrup $O$, Bundgaard $H$, Kyst Madsen J, Christiansen $M$, Andersen PS, Reiber JH: Predictors of coronary in-stent restenosis: importance of angiotensin-converting enzyme gene polymorphism and treatment with angiotensin-converting enzyme inhibitors. I Am Coll Cardiol 200I, 38: I434-I439.

50. Toyofyuku M, Imazu M, Sumii K, Yamamoto H, Hayashi Y, Hiyama K, Kohno N: Influence of angiotensinogen M253T gene polymorphism and an angiotensin converting enzyme inhibitor on restenosis after percutaneous coronary intervention. Atherosclerosis 2002, 160:339-344.

5I. Haberbosch W, Bohle RM, Franke FE, Danilov S, henc-Gelas F, BraunDullaeus R, Hölschermann H, Waas W, Tillmanns H, Gardemann A: The expression of angiotensin-I converting enzyme in human atherosclerotic plaques is not related to the deletion/ insertion polymorphism but to the risk of restenosis after coronary interventions. Atherosclerosis 1997, I30:203-213

52. Canosi U, Angelica Merlini P, Bernardi F, Repetto A, Bramucci E, Ferrario $M$, Angoli L, Gnecchi M, Ferraresi P, Marchetti G, Tavazzi L, Ardissino D: Angiotensin-converting enzyme insertion/deletion polymorphism and risk of restenosis after directional coronary atherectomy followed by stent implantation. Thromb Haemost 2004, 91 :795-800.

53. Dayi SU, Tartan Z, Terzi S, Kasikcioglu H, Uyarel H, Orhan G, Alper AT, Ciloglu F, Cam N: Influence of angiotensin converting enzyme insertion/deletion polymorphism on long-term total graft occlusion after coronary artery bypass surgery. Heart Surg Forum 2005, 8:E373-E377.

54. Ortlepp JR, Janssens U, Bleckmann F, Lauscher J, Merkelbach-Bruse S, Hanrath P, Hoffmann R: A chymase gene variant is associated with atherosclerosis in venous coronary artery bypass grafts. Coron Artery Dis 200I, I 2:493-497.

55. Volzke H, Engel J, Kleine V, Schwahn C, Dahm JB, Eckel L, Rettig R: Angiotensin I-converting enzyme insertion/deletion polymorphism and cardiac mortality and morbidity after coronary artery bypass graft surgery. Chest 2002, I 22:3|-36.

56. Voors AA, van Geel PP, Oosterga M, Buikema $H$, van Veldhuisen DJ, van Gilst WH: Vascular effects of quinapril completely depend on ACE insertion/deletion polymorphism. J Renin Angiotensin Aldosterone Syst 2004, 5: I30-I34.

57. Arnett DK, Davis BR, Ford CE, Boerwinkle E, Leiendecker-Foster C Miller MB, Black H, Eckfeldt JH: Pharmacogenetic association of the angiotensin-converting enzyme insertion/deletion polymorphism on blood pressure and cardiovascular risk in relation to antihypertensive treatment: the Genetics of Hypertension-Associated Treatment (GenHAT) study. Circulation 2005, I I I:3374-3383.

58. Harrap SB, Tzourio C, Cambien F, Poirier O, Raoux S, Chalmers J, Chapman N, Colman S, Leguennec S, MacMahon S, Neal B, Ohkubo T, Woodward M, PROGRESS Collaborative Group: The ACE gene I/D polymorphism is not associated with the blood pressure and cardiovascular benefits of ACE inhibition. Hypertension 2003, 42:297-303.

59. Marciante KD, Bis JC, Rieder MJ, Reiner AP, Lumley T, Monks SA, Kooperberg C, Carlson C, Heckbert SR, Psaty BM: Renin-angiotensin system haplotypes and the risk of myocardial infarction and stroke in pharmacologically treated hypertensive patients. Am J Epidemiol 2007, 166:19-27.

60. Pinto YM, van Gilst WH, Kingma JH, Schunkert H: Deletion-type allele of the angiotensin-converting enzyme gene is associated with progressive ventricular dilation after anterior myocardial infarction. Captopril and Thrombolysis Study Investigators. J Am Coll Cardiol 1995, 25:1622-1626. 
6I. Zee RY, Solomon SD, Ajani UA, Pfeffer MA, Lindpaintner K: A prospective evaluation of the angiotensin-converting enzyme $D$ I I polymorphism and left ventricular remodeling in the 'Healing and Early Afterload Reducing Therapy' study. Clin Genet 2002, 6 I:2I-25

62. Kennon S, Barakat K, Hitman GA, Price CP, Mills PG, Ranjadayalan K, Cooper J, Clark H, Timmis AD: Angiotensin-converting enzyme inhibition is associated with reduced troponin release in nonST-elevation acute coronary syndromes. J Am Coll Cardiol 200 I, 38:724-728.

63. Prasad A, Narayanan S, Husain S, Padder F, Waclawiw M, Epstein N, Quyyumi AA: Insertion-deletion polymorphism of the ACE gene modulates reversibility of endothelial dysfunction with ACE inhibition. Circulation 2000, 102:35-4I.

64. Trevelyan J, Needham EW, Morris A, Mattu RK: Comparison of the effect of enalapril and losartan in conjunction with surgical coronary revascularisation versus revascularisation alone on systemic endothelial function. Heart 2005, 9 I: I 053-1057.

65. Pedersen OD, Gram J, Jeunemaitre X, Billaud E, Jespersen J: Does long-term angiotensin converting enzyme inhibition affect the concentration of tissue-type plasminogen activator-plasminogen activator inhibitor- $I$ in the blood of patients with a previous myocardial infarction. Coron Artery Dis 1997, 8:283-291.

66. Jeron A, Hengstenberg C, Engel S, Lowel H, Riegger GA, Schunkert $\mathrm{H}$, Holmer S: The D-allele of the ACE polymorphism is related to increased QT dispersion in $\mathbf{6 0 9}$ patients after myocardial infarction. Eur Heart J 200I, 22:663-668.

67. Steeds RP, Fletcher J, Parry H, Chowdhary S, Channer KS, West J, Townend JN: The angiotensin-converting enzyme gene I/D polymorphism and heart rate variability following acute myocardial infarction. Clin Auton Res 2002, I 2:66-7I.

68. Zee AH Maitland-van der, Boerwinkle E, Arnett DK, Davis BR, Leiendecker-Foster C, Miller MB, Klungel OH, Ford CE, Eckfeldt JH: Absence of an interaction between the angiotensin-converting enzyme insertion-deletion polymorphism and pravastatin on cardiovascular disease in high-risk hypertensive patients: the Genetics of Hypertension-Associated Treatment (GenHAT) study. Am Heart J 2007, I 53:54-58.

69. Zee $\mathrm{AH}$ Maitland-van der, Stricker $\mathrm{BH}$, Klungel $\mathrm{OH}$, Kastelein J], Hofman A, Witteman JC, Leufkens HG, Duijn CM, Boer AdA: Effectiveness of HMG-CoA reductase inhibitors is modified by the ACE insertion deletion polymorphism. Atherosclerosis 2004, I 75:377-379.

70. Bray PF, Cannon CP, Goldschmidt-Clermont P, Moye LA, Pfeffer MA, Sacks FM, Braunwald E: The platelet $P I(A 2)$ and angiotensinconverting enzyme (ACE) D allele polymorphisms and the risk of recurrent events after acute myocardial infarction. Am J Cardiol 200I, 88:347-352.

7I. Marian AJ, Safavi F, Ferlic L, Dunn JK, Gotto AM, Ballantyne CM: Interactions between angiotensin-I converting enzyme insertion/deletion polymorphism and response of plasma lipids and coronary atherosclerosis to treatment with fluvastatin: the lipoprotein and coronary atherosclerosis study. J Am Coll Cardiol 2000, 35:89-95.

72. Talmud PJ, Watts GF, McBride S, Mandalia S, Brunt JN, Coltart DJ, Lewis B, Humphries SE: Angiotensin converting enzyme gene polymorphism and the course of angiographically defined coronary artery disease. Atherosclerosis 1995, I | 4: I 33-I 35.

73. Defoor J, Vanhees L, Martens K, Matthijs G, Van VA, Zielinska D, Schepers D, Vlietinck R, Fagard R: The CAREGENE study: ACE gene I/D polymorphism and effect of physical training on aerobic power in coronary artery disease. Heart 2006, 92:527-528.

74. Iwanaga Y, Nishi I, Ono K, Takagi S, Tsutsumi Y, Ozaki M, Noguchi T, Takaki H, Iwai N, Nonogi H, Goto $Y$ : Angiotensin-converting enzyme genotype is not associated with exercise capacity or the training effect of cardiac rehabilitation in patients after acute myocardial infarction. Circ J 2005, 69:13/5-1319.

75. Kastrati A, Mehilli J, Pache J, Kaiser C, Valgimigli M, Kelbaek H, Menichelli M, Sabaté M, Suttorp MJ, Baumgart D, Seyfarth M, Pfisterer ME Schömig A: Analysis of 14 trials comparing sirolimus-eluting stents with bare-metal stents. N Engl J Med 2007, 356:1030-1039.

76. Betriu A, Masotti M, Serra A, Alonso J, Fernandez-Aviles F, Gimeno F, Colman T, Zueco J, Delcan JL, García E, Calabuig J: Randomized comparison of coronary stent implantation and balloon angioplasty in the treatment of de novo coronary artery lesions
(START): a four-year follow-up. I Am Coll Cardiol 1999 34:|498-1506.

77. Keavney B: Outcome following percutaneous coronary intervention: not, so far, in our genes. Heart 2003, 89:247-248.

78. Welt FG, Rogers C: Inflammation and restenosis in the stent era. Arterioscler Thromb Vasc Biol 2002, 22:1769-1776.

79. McKenzie CA, Abecasis GR, Keavney B, Forrester T, Ratcliffe PJ, Julier C, Connell JM, Bennett F, McFarlane-Anderson N, Lathrop GM, Cardon LR: Trans-ethnic fine mapping of a quantitative trait locus for circulating angiotensin l-converting enzyme (ACE). Hum Mol Genet 200I, I 0:1077-1084.

80. Dhawan J, Bray CL: Are Asian coronary arteries smaller than Caucasian? A study on angiographic coronary artery size estimation during life. Int J Cardiol 1995, 49:267-269.

8I. Balk EM, Bonis PA, Moskowitz H, Schmid CH, loannidis JP, Wang C, Lau J: Correlation of quality measures with estimates of treatment effect in meta-analyses of randomized controlled trials. JAMA 2002, 287:2973-2982.

82. Bavry AA, Bhatt DL: Appropriate use of drug-eluting stents: balancing the reduction in restenosis with the concern of late thrombosis. Lancet 2008, 37 1:2 1 34-2 143.

83. Zhu X, Bouzekri N, Southam L, Cooper RS, Adeyemo A, McKenzie CA, Luke A, Chen G, Elston RC, Ward R: Linkage and association analysis of angiotensin I-converting enzyme (ACE)-gene polymorphisms with ACE concentration and blood pressure. Am J Hum Genet 200 I, 68: I I39-I I 48.

84. Cordell HJ: Epistasis: what it means, what it doesn't mean, and statistical methods to detect it in humans. Hum Mol Genet 2002, I I :2463-2468.

85. SEARCH Collaborative Group, Link E, Parish S, Armitage J, Bowman L, Heath S, Matsuda F, Gut I, Lathrop M, Collins R: SLCOI B I variants and statin-induced myopathy - a genomewide study. $N$ Engl J Med 2008, 359:789-799.

86. Veenstra DL, Higashi MK, Phillips KA: Assessing the cost-effectiveness of pharmacogenomics. AAPS PharmSci 2000, 2:E29.

87. Zee AH Maitland-van der, Klungel $\mathrm{OH}$, Stricker BH, Veenstra DL, Kastelein JJ, Hofman A, Witteman JC, Leufkens HG, van Duijn CM, de Boer A: Pharmacoeconomic evaluation of testing for angiotensin-converting enzyme genotype before starting betahydroxy-beta-methylglutaryl coenzyme $A$ reductase inhibitor therapy in men. Pharmacogenetics 2004, I4:53-60.

\section{Pre-publication history}

The pre-publication history for this paper can be accessed here:

\section{http://www.biomedcentral.com/1471-2350/10/50/pre} pub
Publish with Bio Med Central and every scientist can read your work free of charge

"BioMed Central will be the most significant development for disseminating the results of biomedical research in our lifetime. "

Sir Paul Nurse, Cancer Research UK

Your research papers will be:

- available free of charge to the entire biomedical community

- peer reviewed and published immediately upon acceptance

- cited in PubMed and archived on PubMed Central

- yours - you keep the copyright
BioMedcentral 